\title{
Article \\ High Integrity and Fidelity of Long-Term Cryopreserved Umbilical Cord Blood for Transplantation
}

\author{
Gee-Hye Kim ${ }^{1}{ }^{1}$, Jihye Kwak ${ }^{1}$, Sung Hee Kim ${ }^{2}$, Hee Jung Kim ${ }^{2}$, Hye Kyung Hong ${ }^{2}$, Hye Jin Jin ${ }^{1}$, Soo Jin Choi ${ }^{1}$, \\ Wonil Oh ${ }^{1,2, *}$ and Soyoun $\mathrm{Um}^{1, *(\mathbb{D}}$ \\ 1 Biomedical Research Institute, MEDIPOST Co., Ltd., Seongnam-si, Gyeonggi-do 13494, Korea; \\ haha38@medi-post.co.kr (G.-H.K.); jihyek@medi-post.co.kr (J.K.); genny77@medi-post.co.kr (H.J.J.); \\ sjchoi@medi-post.co.kr (S.J.C.) \\ 2 Cord Blood Bank, MEDIPOST Co., Ltd., Seongnam-si, Gyeonggi-do 13494, Korea; \\ sswan823@medi-post.co.kr (S.H.K.); special@medi-post.co.kr (H.J.K.); genetichong@medi-post.co.kr (H.K.H.) \\ * Correspondence: wioh@medi-post.co.kr (W.O.); ssoso23@medi-post.co.kr (S.U.)
}

Citation: Kim, G.-H.; Kwak, J.; Kim, S.H.; Kim, H.J.; Hong, H.K.; Jin, H.J.; Choi, S.J.; Oh, W.; Um, S. High Integrity and Fidelity of Long-Term Cryopreserved Umbilical Cord Blood for Transplantation. J. Clin. Med. 2021, 10, 293. https://doi.org/10.3390/ jcm10020293

Received: 28 December 2020 Accepted: 11 January 2021 Published: 14 January 2021

Publisher's Note: MDPI stays neutral with regard to jurisdictional clai$\mathrm{ms}$ in published maps and institutional affiliations.

Copyright: (C) 2021 by the authors. Licensee MDPI, Basel, Switzerland. This article is an open access article distributed under the terms and conditions of the Creative Commons Attribution (CC BY) license (https:// creativecommons.org/licenses/by/ $4.0 /)$.

\begin{abstract}
Umbilical cord blood (UCB) is used as a source of donor cells for hematopoietic stem cell (HSC) transplantation. The success of transplantation is dependent on the quality of cord blood (CB) units for maximizing the chance of engraftment. Improved outcomes following transplantation are associated with certain factors of cryopreserved CB units: total volume and total nucleated cell (TNC) count, mononuclear cell (MNC) count, and CD34+ cell count. The role of the storage period of $\mathrm{CB}$ units in determining the viability and counts of cells is less clear and is related to the quality of cryopreserved CB units. Herein, we demonstrate the recovery of viable TNCs and CD34+ cells, as well as the MNC viability in 20-year-old cryopreserved CB units in a CB bank (MEDIPOST Co., Ltd., Seongnam-si, Gyeonggi-do, Korea). In addition, cell populations in CB units were evaluated for future clinical applications. The stable recovery rate of the viability of cryopreserved CB that had been stored for up to 20 years suggested the possibility of uses of the long-term cryopreservation of CB units. Similar relationships were observed in the recovery of TNCs and CD34+ cells in units of cryopreserved and fresh CB. The high-viability recovery of long-term cryopreserved CB suggests that successful hematopoietic stem cell (HSC) transplantation and other clinical applications, which are suitable for treating incurable diseases, may be performed regardless of long-term storage.
\end{abstract}

Keywords: cord blood; long-term cryopreservation; total nucleated cells; recovery

\section{Introduction}

Cell therapy, which plays a central role in regenerative medicine, involves the application of viable cells for treating or curing medical conditions or diseases. Umbilical cord blood (UCB) is a primitive and alternative source of hematopoietic stem cells (HSCs) and serves as a promising and established curative therapeutic agent for hematological malignancies and life-threatening conditions, primarily hematological and immune systemrelated genetic disorders [1-3]. Viable cells have a short shelf-life at ambient temperatures, which complicates their storage and delivery to patients. To overcome this shortcoming of cell therapy, cell and tissue preservation in cord blood (CB) banks is practiced to preserve living cells under artificial conditions [4]. Cryopreservation, which is a process for preserving cells and tissues at significantly low temperatures, is currently the only method that allows the long-term storage of living cells and tissues for several years and up to decades [5]. It is important to retain the viability of frozen cells by maintaining ultralow temperatures with stable conditions for as long as possible [6,7].

$\mathrm{CB}$ banking is increasingly performed for improving chances of potential future transplantation. According to previous reports, UCB contains approximately $10 \%$ less stem cells than bone marrow [8,9], but UCB contains similar numbers of progenitor cells (CD34+ cells) volume per volume with bone marrow. However, CB transplantation does 
not require an exact genetic match. Since the first successful transplantation of cord blood in 1988, quality issues in cord blood specimens have been addressed [10,11]. Therefore, the maintenance of the quality and viability of infused total nucleated cells (TNCs) or CD34+ cells is critical for successful transplantation, owing to retaining adequate cell numbers for future transplantation [12]. Typically, cord blood is processed by depleting red blood cells (RBCs) and plasma. After post-processing with programmable controlled freezing, the $\mathrm{CB}$ unit is transferred to a liquid nitrogen tank and stored at $-196^{\circ} \mathrm{C}$. A previous report demonstrated over $90 \%$ recovery of hematopoietic progenitor cells from cryopreserved CB stored for more than 10-15 years [13].

In this study, we evaluated whether CB banking helps retain the viability of cryopreserved cells stored for up to 20 years. In addition to an efficient storage state, the ability to freeze and retrieve UCB indicates the recovery rate of functional responsive lymphocytes for future therapeutic applications.

\section{Experimental Section}

\subsection{Collection, Cryopreservation, and Separation of UCB Cells}

Human UCB, obtained during deliveries, was collected in blood bags containing $24.5 \mathrm{~mL}$ of citrate phosphate dextrose adenine (CPDA-1) as an anti-coagulant, as described earlier [14]. The study was conducted in accordance with the Declaration of Helsinki, and the protocol was approved by the Korean Public Institutional Review Board (P01202002-31-001). The UCB collection procedure was continued after obtaining informed consent from donors. During a processing step, RBCs and plasma were separated from the specimens and depleted according to a method reported earlier [15]. After depletion of RBC and plasma, $20 \mathrm{~mL}$ of concentrated leukocyte-rich plasma was obtained and added to a freezing bag (ThermoGenesis Corp, Rancho Condova, CA, USA) containing $5 \mathrm{~mL}$ of 10\% cryoprotectant (DMSO/dextran). CB (contained in the bag) was subjected to a controlledrate freezing $(\mathrm{CRF})$ procedure and stored at $-196{ }^{\circ} \mathrm{C}$ in a liquid nitrogen tank (MVE Storage Tank, Chart-MVE, Brentwood, NH, USA). To determine the stability of TNCs, the viable cells were analyzed after processing and before cryopreservation.

For the evaluation of long-term storage stability, three sets of $\mathrm{CB}$ units were analyzed. In the first set, a total of 87 CB units deposited between 2000 and 2011 at MEDIPOST Co., Ltd. and 11 fresh UCB units donated in 2020 were analyzed. Among the cryopreserved $\mathrm{CB}$ units, only the disqualified units owing to insufficient TNC counts were used for the experiments $\left(<7 \times 10^{8}\right.$ cells/unit of TNC), based on the guidelines of the Korea National Laws on Cord Blood Management and Research (2011). In the second set, 116 CB units transplanted between 2001 and 2016 were analyzed. The segments attached to the freezing bags for the $116 \mathrm{CB}$ units were used to assess the viability and TNC cell count recovery before transplantation. In the third set, for long-term tracing, $40 \mathrm{CB}$ units donated from 2009 to 2018 were used. For assessing the long-term storage stability, the viability, TNC count, and CD34+ cells count were evaluated every year for 1-10 years. Each CB unit was divided into multiple segments. Each vial (total 215) was analyzed annually after thawing.

\subsection{Hematological Cell Counts and Enumeration of CD34+ Cells}

The TNC count was determined before and after cryopreservation using a hematology analyzer (Siemens ADVIA2120 and ADVIA 2120i, Malvern, PA, USA). CD34+ cells were quantified using a stem cell enumeration kit (BD Biosciences, Franklin Lakes, NJ, USA) according to the manufacturer's instructions. CD45-fluorescein isothiocyanate (FITC) and CD34-phycoerythrin (PE) antibodies (BD Biosciences, PharMingen, San Jose, CA, USA) were used to detect the leucocytes and hematopoietic stem/precursor cells, respectively. 7-Aminoactinomycin (7-AAD, BD Bioscience), a nucleic acid dye, was used for evaluating cell viability. Flow cytometry was performed using a flow cytometer (before processing: BD FACSCalibur, Beckton Dickinson, San Jose, CA, USA and after processing: MACSQuant, Miltenyi Biotec, Bergisch Gladbach, North Rhine-Westphalia, Germany). 


\subsection{Cell Viability Evaluation}

Trypan blue dye-exclusion was performed to measure the viability of mononuclear cells (MNCs). An Annexin V-FITC early apoptosis detection kit (Cell Signaling, Boston, MA, USA) was used to evaluate cell viability and detect apoptosis according to the suggested protocol. The stained cells were analyzed using a flow cytometer (MACSQuant).

\subsection{Frequencies of Cell Types in UCB}

To analyze the cell populations and types, MNCs were isolated using Ficoll-Hypaque solution (GE Healthcare, Uppsala, Sweden) according to the suggested protocol. The MNCs were washed and resuspended with phosphate buffer saline (PBS) to assess and analyze the surface markers. The cells were incubated with human CD34, CD14, and CD3-phycoerythrin (PE) antibodies and stained with CD19-fluorescein isothiocyanate (FITC), CD56-Alexa 488, and CD45-allophycocyanin (BD Biosciences). Isotype controls were matched to detect nonspecific background signals corresponding to negative controls. The cells were analyzed using a flow cytometer (MACSQuant).

\subsection{Statistical Analysis}

Data are presented as mean \pm standard deviation (SD). Statistical analysis involved multiple comparisons using one-way analysis of variance (ANOVA), followed by Bonferroni's multiple comparisons test using Prism 7 software (GraphPad, San Diego, CA, USA). A $p<0.05$ was considered to represent a statistically significant difference.

\section{Results}

\subsection{Recovery of Viability, TNCs, and Total CD34+ Cells from Cryopreserved UCB}

To evaluate the phenotype of cryopreserved CB, the number of TNCs, total CD34+ cells, and viable cells were determined before and after cryopreservation. The cryopreserved CB units remained stored from 2001 to 2011. The storage periods for the CB units ranged from 10 to 20 years. Eighty-seven units were used for the analysis of viability, TNC count, and total CD34+ cell count before and after cryopreservation. Viability recovery rate was observed in $99.8 \pm 4.0 \%$ of the CB units. There was no significant difference between the units based on the storage periods. The average cell viability rate before and after cryopreservation was $87.8 \pm 3.5 \%$ and $87.6 \pm 4.0 \%$, respectively $(p>0.99)$. The average TNCs count was $6.1 \pm 0.6(\times 108 /$ unit $)$ at storage and $6.1 \pm 0.7(\times 108$ cells/unit $)$ after thawing. The average total CD34+ cell counts ranged from 0.9 to 6.4 ( $\times 106$ cells/unit $)$ at storage, and the average total CD34+ cells ranged from 0.8 to 5.7 ( $\times 106$ cells $/$ unit $)$ after thawing. The average recovery rate of TNCs in all the CB units was $97.9 \pm 9.4 \%(p>0.06)$, while the average recovery rate of CD34+ cells was $93.8 \pm 18.0 \%(p>0.99)$. The recovery rates of TNCs and total CD34+ cells did not differ significantly between CB units with different storage periods (Figure 1).

\subsection{Long-Term Storage Stability (from 1 to 10 Years)}

Data for the counts of viable cells, TNCs, and CD34+ cells in the CB units were recorded between 1 and 10 years. Long-term storage efficacy was evaluated by tracing the number of viable cells, TNCs, and CD34+ cells for the 10 years. The donated CB units $(n=40)$ were stored, and the hematological and CD34+ cell counts were determined annually using a flow cytometer. The average recovery rates of viable cells, TNCs, and CD34+ cells in total CB units were $96.6 \pm 4.0 \%, 86.2 \pm 7.0 \%$, and $82.0 \pm 19.8 \%$, respectively. The recovery rates of viable cells, TNCs, and CD34+ cells were not affected significantly by the storage period, as observed when the segment was inspected annually (Table 1).

\subsection{Population of MNCs Isolated in Cryopreserved and Fresh UCB}

Cryopreserved and fresh CB units were subjected to flow cytometric analysis, and a scatter plot was generated. After RBC depletion, whole CB cells were represented on a scatter plot that revealed the presence of three major components: lymphocytes, 
monocytes, and granulocytes. The three distinct cell populations are indicated with green (granulocytes), blue (monocytes), and red (lymphocytes) (Figure S1A,C). MNCs from the cryopreserved and fresh $\mathrm{CB}$ samples showed the depletion of granulocytes after Ficoll separation (Figure S1B,D). After RBC depletion and Ficoll separation, cell populations in MNCs from cryopreserved CB revealed $8.5 \pm 8.2 \%$ of monocytes and $93.0 \pm 4.7 \%$ of lymphocytes populations. The percentages of monocytes and lymphocytes in MNCs isolated from fresh CB were $8.6 \pm 4.3 \%$ and $98.0 \pm 2.3 \%$, respectively. There was no significant difference in the cell populations between cryopreserved and fresh CB samples (Figure S1, Table 2).

A
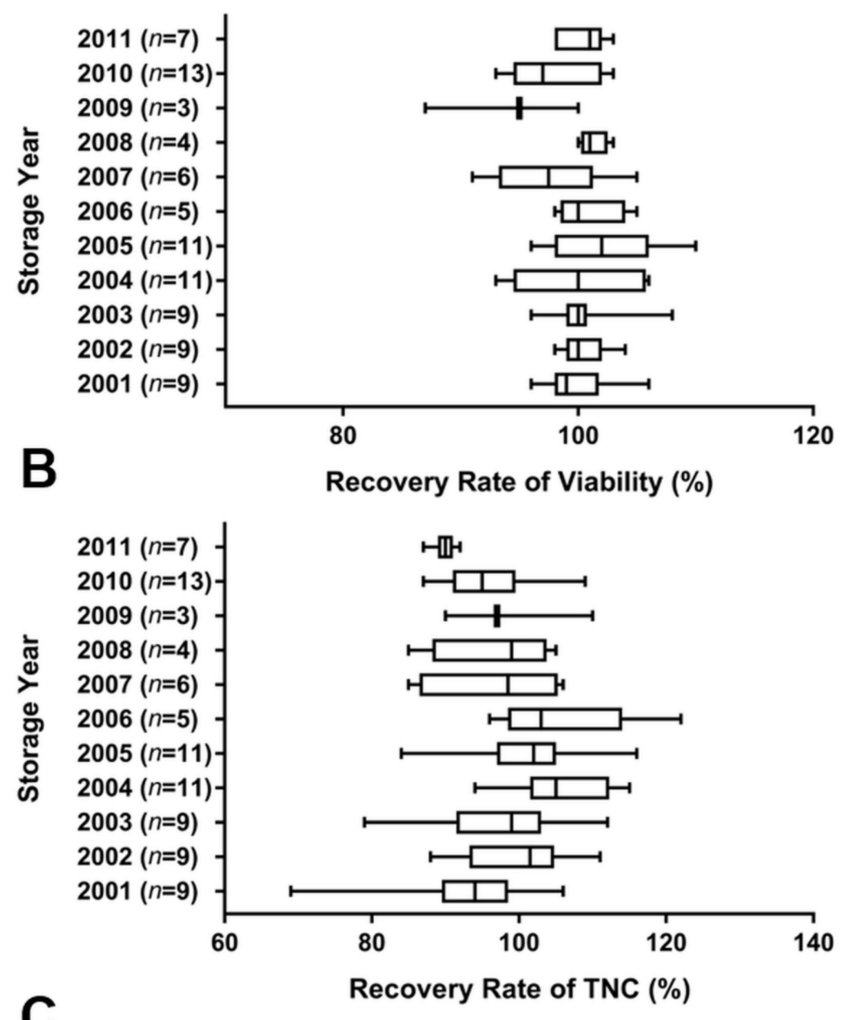

C

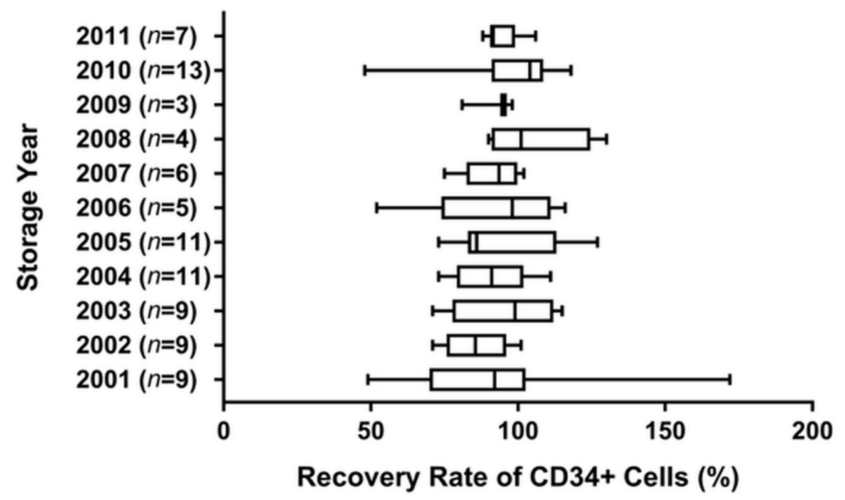

Figure 1. Recovery rates of viability (A), TNCs (B), and total CD34+ cells (C) from 87 cryopreserved human CB units stored from 2001 to 2011 . The viability and the cell types were analyzed before and after cryopreservation. The average recovery rates of viability, TNC count, and total CD34+ cell count in total cryopreserved CB were $99.8 \pm 4.0 \%, 98.2 \pm 8.7 \%$, and $93.8 \pm 18.0 \%$, respectively. Values of $p>0.99$ (A), $p>0.06$ (B), and $p>0.99$ (C) indicated no significant difference between samples with different cryopreservation periods. Data are presented as mean \pm standard deviation of mean. Abbreviations: CB, cord blood; TNCs, total nucleated cells. 
Table 1. Tracing of recovery rate of viability, TNCs, and CD34+ cells from 40 cryopreserved human umbilical cord blood units by checking CBs annually for 10 years (AVE \pm SD, \%).

\begin{tabular}{ccccc}
\hline $\begin{array}{c}\text { Storage Duration } \\
\text { (Years) }\end{array}$ & $\begin{array}{c}\text { Total Check Point } \\
\text { (Annual) }\end{array}$ & $\begin{array}{c}\text { Recovery Rate of } \\
\text { Viability (\%) }\end{array}$ & $\begin{array}{c}\text { Recovery Rate of } \\
\text { TNCs (\%) }\end{array}$ & $\begin{array}{c}\text { Recovery Rate of } \\
\text { CD34+ Cells (\%) }\end{array}$ \\
\hline 10 & 3 & $94.6 \pm 1.0$ & $80.5 \pm 2.7$ & $66.0 \pm 14.9$ \\
\hline 9 & 7 & $93.4 \pm 3.3$ & $80.9 \pm 4.6$ & $81.0 \pm 19.4$ \\
\hline 8 & 12 & $96.5 \pm 4.3$ & $80.7 \pm 4.4$ & $80.8 \pm 22.9$ \\
\hline 7 & 16 & $96.2 \pm 4.6$ & $82.3 \pm 4.3$ & $82.7 \pm 18.7$ \\
\hline 6 & 20 & $96.6 \pm 4.1$ & $84.7 \pm 5.1$ & $83.9 \pm 18.0$ \\
\hline 5 & 24 & $96.2 \pm 4.0$ & $86.8 \pm 4.9$ & $78.0 \pm 22.2$ \\
\hline 4 & 28 & $96.7 \pm 3.5$ & $85.9 \pm 9.4$ & $80.2 \pm 20.6$ \\
\hline 3 & 32 & $96.8 \pm 3.6$ & $87.0 \pm 7.2$ & $81.9 \pm 23.5$ \\
\hline 2 & 36 & $97.5 \pm 3.6$ & $87.9 \pm 6.7$ & $82.5 \pm 17.7$ \\
\hline 1 & 37 & $96.7 \pm 4.9$ & $89.4 \pm 6.9$ & $86.0 \pm 17.4$ \\
\hline Total & 215 & $96.6 \pm 4.0$ & $86.2 \pm 7.0$ & $82.0 \pm 19.8$ \\
\hline
\end{tabular}

Abbreviations: AVE, average; SD, standard deviation; TNCs, total nucleated cells.

Table 2. Cell populations in MNCs isolated from 20-year cryopreserved and fresh umbilical cord blood (AVE $\pm \mathrm{SD}, \%$ ).

\begin{tabular}{|c|c|c|c|c|c|c|c|}
\hline $\begin{array}{c}\text { Storage } \\
\text { Year }\end{array}$ & $n$ & $\begin{array}{c}\text { CD45+ } \\
\text { Lymphocytes }\end{array}$ & $\begin{array}{c}\text { CD14+ } \\
\text { Monocyte }\end{array}$ & $\begin{array}{l}\text { CD34+ } \\
\text { HSCs }\end{array}$ & $\begin{array}{c}\text { CD45+/CD3+ } \\
\text { T Cells }\end{array}$ & $\begin{array}{c}\text { CD45+/CD19+ } \\
\text { B Cells }\end{array}$ & $\begin{array}{c}\text { CD56+ } \\
\text { Im/m NK Cells }\end{array}$ \\
\hline 2000 & 10 & $90.8 \pm 3.6$ & $9.0 \pm 5.7$ & $0.6 \pm 0.5$ & $46.2 \pm 16.8$ & $0.3 \pm 0.4$ & $0.3 \pm 0.3$ \\
\hline 2001 & 5 & $95.1 \pm 1.4$ & $11.8 \pm 15.8$ & $0.4 \pm 0.4$ & $47.5 \pm 11.1$ & $1.3 \pm 0.9$ & $0.4 \pm 0.1$ \\
\hline 2002 & 5 & $93.1 \pm 3.9$ & $10.6 \pm 4.1$ & $0.8 \pm 1.0$ & $37.1 \pm 13.5$ & $1.5 \pm 1.6$ & $0.4 \pm 0.3$ \\
\hline 2003 & 4 & $92.9 \pm 5.6$ & $3.6 \pm 2.0$ & $0.4 \pm 0.4$ & $37.9 \pm 16.2$ & $1.7 \pm 1.2$ & $0.4 \pm 0.3$ \\
\hline 2004 & 4 & $93.3 \pm 5.8$ & $8.0 \pm 11.1$ & $0.3 \pm 0.2$ & $36.7 \pm 5.7$ & $0.3 \pm 0.2$ & $0.1 \pm 0.1$ \\
\hline 2005 & 8 & $90.6 \pm 6.2$ & $5.8 \pm 4.8$ & $0.4 \pm 0.3$ & $51.0 \pm 12.7$ & $0.4 \pm 0.2$ & $0.3 \pm 0.4$ \\
\hline 2006 & 4 & $92.1 \pm 6.2$ & $5.0 \pm 0.8$ & $0.5 \pm 0.2$ & $60.5 \pm 22.9$ & $1.0 \pm 1.2$ & $1.3 \pm 2.1$ \\
\hline 2007 & 4 & $94.3 \pm 5.6$ & $5.2 \pm 4.5$ & $0.2 \pm 0.1$ & $65.3 \pm 12.9$ & $1.1 \pm 1.0$ & $0.2 \pm 0.1$ \\
\hline 2008 & 4 & $94.1 \pm 2.3$ & $5.1 \pm 5.4$ & $0.6 \pm 0.4$ & $35.3 \pm 26.5$ & $1.4 \pm 1.1$ & $0.1 \pm 0.1$ \\
\hline 2009 & 4 & $93.7 \pm 2.8$ & $3.8 \pm 1.5$ & $0.2 \pm 0.2$ & $34.9 \pm 14.8$ & $1.2 \pm 1.1$ & $0.1 \pm 0.1$ \\
\hline 2010 & 10 & $94.5 \pm 6.2$ & $12.2 \pm 9.8$ & $0.5 \pm 0.2$ & $53.9 \pm 9.8$ & $0.7 \pm 0.6$ & $0.3 \pm 0.4$ \\
\hline 2011 & 4 & $94.6 \pm 3.2$ & $10.1 \pm 12.4$ & $0.2 \pm 0.1$ & $38.9 \pm 9.3$ & $0.8 \pm 0.7$ & $0.2 \pm 0.2$ \\
\hline Total & 66 & $93.0 \pm 4.7$ & $8.5 \pm 8.2$ & $0.5 \pm 0.4$ & $46.4 \pm 15.5$ & $0.8 \pm 0.8$ & $0.3 \pm 0.6$ \\
\hline Fresh & 6 & $98.0 \pm 2.3$ & $8.6 \pm 4.3$ & $0.6 \pm 0.6$ & $56.8 \pm 10.0$ & $1.5 \pm 0.4$ & $0.7 \pm 0.4$ \\
\hline
\end{tabular}

Abbreviations: AVE, average; Im/m, immature/mature; MNCs, mononuclear cells; HSCs, hematopoietic stem cells; NK, natural killer; SD, standard deviation.

Cell populations in MNCs isolated from CB were analyzed using antibodies. A comparison of the six types is illustrated in Table 2. The mean percentage of each cell type among the leukocytes in CB units (total 66 lots) cryopreserved from 2000 to 2011 was indicated and compared with leukocytes from fresh CB samples (total 6 lots). The results included the stem cell population in $\mathrm{MNCs}$ from cryopreserved $\mathrm{CB}$, including that of CD34+ HSCs $(0.5 \pm 0.4 \%)$ and immune cell populations, such as CD3+ T lymphocytes $(46.4 \pm 15.5 \%), C D 19+$ B lymphocytes $(0.8 \pm 0.8 \%)$, and CD56+ natural killer cells $(0.3 \pm 0.6 \%)$. Cell populations in MNCs from fresh CB revealed CD3+ T lymphocytes $(56.8 \pm 10.0 \%), \mathrm{CD} 19+\mathrm{B}$ lymphocytes $(1.5 \pm 0.4 \%)$, and CD56+ natural killer cells $(0.7 \pm 0.4 \%)$. There was no significant difference between the mean percentages of each cell type in cryopreserved and fresh CB units $(p>0.99)$. 


\subsection{Comparison of MNC Viability in Cryopreserved and Fresh UCB}

MNCs, a mixture of angiogenic stem and progenitor cells, non-hematopoietic cells, and hematopoietic cells were separated using Ficoll density gradient centrifugation. The viability of MNCs isolated from long-term cryopreserved CB stored from 2000 to 2011 was compared to that of MNCs isolated from fresh CB. After separation using Ficoll, the mean percentages of viable MNCs isolated from cryopreserved $\mathrm{CB}$ and fresh $\mathrm{CB}$ were $93.6 \pm 1.4 \%$ and $96.4 \pm 2.8 \%$, respectively. There was no significant difference between the mean percentage of viability of MNCs isolated from cryopreserved and fresh CB $(p>0.99)$. The results show that the viability of MNCs remained unaffected by the storage period (Figure 2A), as indicated by the levels of apoptosis determined using Annexin $\mathrm{V} /$ propidium iodide double staining performed using MNCs isolated from cryopreserved CB units (2000, 2005, and 2010) and fresh CB units. The assessment of MNC viability in 2000, 2005, and 2010 indicated that the viable MNC count did not differ significantly in $\mathrm{CB}$ cryopreserved for different periods. MNCs isolated from samples cryopreserved in 2000,2005 , and 2010 showed a mean viability of $88.3 \pm 4.2 \%, 88.0 \pm 2.3 \%$, and $87.1 \pm 4.4 \%$, respectively, whereas those isolated from fresh CBs showed a mean viability of $94.4 \pm 1.6 \%$. The overall proportions of dead, necrotic, and apoptotic cells among cryopreserved MNCs did not differ significantly from those among fresh MNCs (Figure 2B). The viability of CD34+ cells on total nucleated cells was observed with 7-AAD staining. Average viability of CD34+ cells isolated from CB cryopreserved in $2000(85.6 \pm 6.1 \%), 2005(88.3 \pm 5.2 \%)$, and $2010(83.7 \pm 4.5 \%)$, and from fresh CB $(86.4 \pm 3.8 \%)$ was $86.0 \pm 4.9 \%$. There was no significant difference in the viability of CD34+ cells from cryopreserved and fresh CB (Figure 2C). There was no significant change in MNCs and CD34+ cell viability and apoptosis in $\mathrm{CB}$ units stored for over 20 years. To confirm that long-term cryopreserved cells were still functionally viable, a colony forming unit (CFU) assay was performed using MNCs isolated from CB stored in 2000, 2005, and 2010. Compared to MNCs isolated from fresh $\mathrm{CB}$, the number of CFU-GM (granulocyte-macrophage) had no significant difference $(p=0.32)$. Overall, the results show that long-term storage CB units had no significant difference on the functional viability and potency of MNCs and CD34+ cells.

\subsection{Characteristics of Store CB Units Used for Transplantation}

Table 3 summarizes data on the cryopreservation period (time interval between donation and transplantation), TNC count, total CD34+ cells, and viability of CB units. To determine the impact of cryopreservation on TNC counts and CD34+ cells, TNC counts and CD34+ cells before and after cryopreservation of CB units used for transplantation were determined. For HSC transplantation, $3.8 \pm 2.9$ years of cryopreservation period were considered. Overall, $557 \mathrm{CB}$ units used for transplantation showed a mean viability of $83.2 \pm 5.7 \%$ at transplantation. The TNC counts were $9.8 \pm 3.9\left(\times 10^{8}\right.$ cells/unit $)$ at the storage year and $9.8 \pm 4.0\left(\times 10^{8}\right.$ cells/unit $)$ at the transplantation year. These results indicate that the cryopreservation period did not affect the viability and TNC counts (Table 3 ). 
Table 3. Characteristics of 557 patients receiving CB transplantation.

\begin{tabular}{|c|c|c|}
\hline Parameter & Number & Range \\
\hline CB unit cryopreservation, yr & $n$ & - \\
\hline$\leq 5$ & 429 & - \\
\hline 5.1 to 10 & 111 & - \\
\hline 10.1 to 15 & 16 & - \\
\hline 15.1 to 21 & 1 & - \\
\hline TNC $\left(\times 10^{8} /\right.$ unit $)$ & $\mathrm{AVE} \pm \mathrm{SD}$ & Range \\
\hline Pre-TNC & $9.8 \pm 3.9$ & 1.1 to 32.4 \\
\hline Post-TNC & $9.8 \pm 4.0$ & 1.1 to 32.2 \\
\hline CD34+ cells $\left(\times 10^{6} /\right.$ unit $)$ & $\mathrm{AVE} \pm \mathrm{SD}$ & Range \\
\hline Pre-CD34+ cells & $4.1 \pm 2.8$ & 0.5 to 23.6 \\
\hline Post-CD34+ cells & $3.9 \pm 2.7$ & 0.4 to 19.0 \\
\hline Post-thaw viability (\%) & $\mathrm{AVE} \pm \mathrm{SD}$ & Range \\
\hline Viability & $83.2 \pm 5.7$ & 60.0 to 96.0 \\
\hline HLA matching & $n$ & - \\
\hline $6 / 6$ or $5 / 6$ & 441 & - \\
\hline $4 / 6$ or less & 116 & - \\
\hline ABO match & $n$ & - \\
\hline Match & 246 & - \\
\hline Minor Mismatch & 297 & - \\
\hline Major Mismatch & 14 & - \\
\hline Recipient gender & $n$ & - \\
\hline Male & 336 & - \\
\hline Female & 200 & - \\
\hline Unknown & 21 & - \\
\hline Recipient age, year & $n$ & - \\
\hline$\leq 5$ & 197 & - \\
\hline 5.1 to 10 & 155 & - \\
\hline$>10.1$ & 189 & - \\
\hline Unknown & 16 & - \\
\hline Recipient Weight, kg & $n$ & - \\
\hline$\leq 10$ & 57 & - \\
\hline 10.1 to 30 & 225 & - \\
\hline 30.1 to 60 & 124 & - \\
\hline$>60$ & 67 & - \\
\hline Unknown & 84 & - \\
\hline Autologous vs. Allogenic & $n$ & - \\
\hline Autologous & 78 & - \\
\hline Allogenic & 479 & - \\
\hline Diagnosis & $n$ & - \\
\hline Chronic myeloid leukemia (CML) & 18 & - \\
\hline Acute myeloid leukemia (AML) & 161 & - \\
\hline Acute lymphoblastic leukemia (ALL) & 152 & - \\
\hline Aplastic anemia & 26 & - \\
\hline Hemophagocytic lymphohistiocytosis (HLH) & 11 & - \\
\hline Cerebral palsy & 38 & - \\
\hline Developmental disability & 34 & - \\
\hline Others & 117 & - \\
\hline
\end{tabular}

Abbreviations: AVE, average; SD, standard deviation; TNCs, total nucleated cells; HLA, human leukocyte antigen; $\mathrm{ABO}, \mathrm{ABO}$ blood type 
A

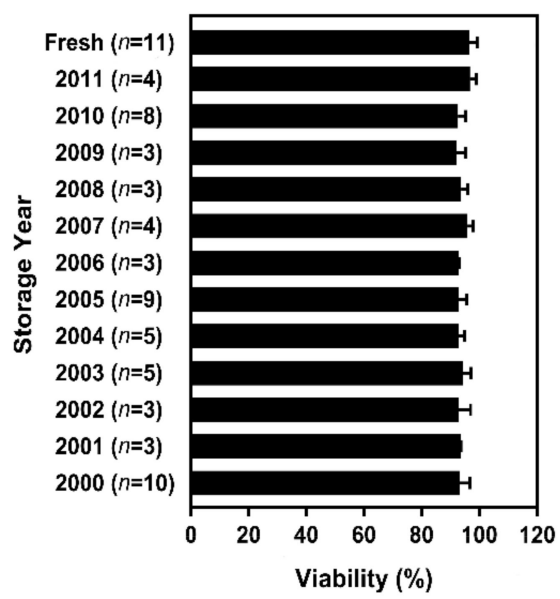

C

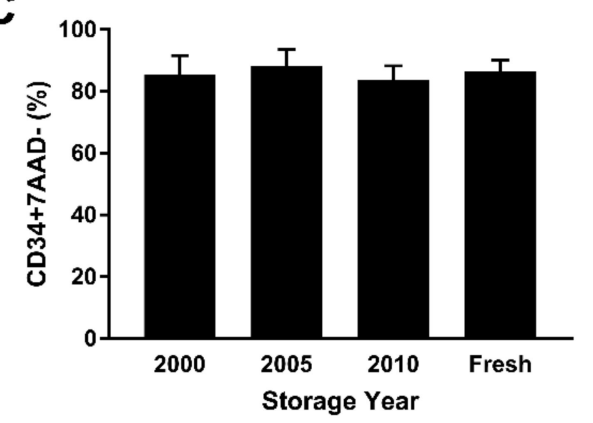

B
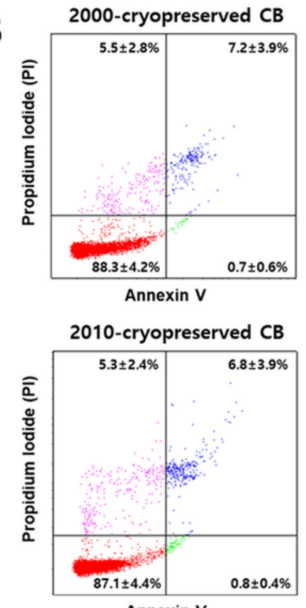

Annexin $V$

D

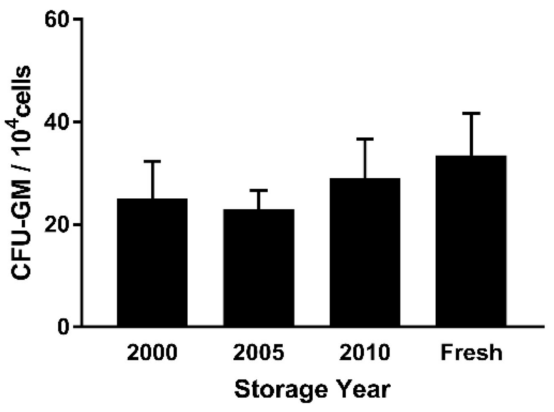

Figure 2. Comparison of MNC viability in long-term cryopreserved and fresh umbilical CB samples by Annexin V/propidium iodide staining. (A) After RBC depletion and Ficoll separation, MNC viability was assessed in 60 cryopreserved CB units (stored from 2000 to 2011) and 11 fresh CB units. There was no significant difference between MNC viabilities in cryopreserved and fresh CB units $(p>0.99)$. The average viability percentage was $93.6 \pm 1.4 \%$. (B) Annexin $\mathrm{V} /$ propidium iodide staining revealed that there was no correlation between cryopreservation period and cell viability. (C) The viability of CD34+ cells in cryopreserved (3 units stored from 2000, 2005, and 2010) and fresh CB (3 units) was analyzed by flow cytometry with 7-AAD staining. (D) In vitro CFU-GM assay provided the colony number of granulocytemacrophage progenitor cells for 14-day culture period $(p=0.32)$. Data are presented as mean \pm standard deviation of mean. Abbreviations: $\mathrm{CB}$, cord blood; $\mathrm{MNCs}$, mononuclear cells; 7-AAD, 7-Aminoactinomycin; CFU-GM: colony-forming unit-granulocyte, macrophage.

\section{Discussion}

To date, $\mathrm{CB}$ has been used as a source of hematopoietic stem and progenitor cells in over 40,000 clinical hematopoietic cell transplantations to treat hematological, metabolic, immunological, neoplastic, and neurological disorders. Approximately 5 million units of CB are stored in public and private cord banks worldwide [4]. This study presented an opportunity to assess the quality of cryopreserved $\mathrm{CB}$ units stored in private Korean cord banks since 2000. Owing to the requirements for rigorous processing and cryopreservation before transplantation, the final quality of long-term cryopreserved $C B$ units remains uncertain. The study aimed to assess critical factors for $\mathrm{CB}$ recovery rates, including viability, TNC count, and CD34+ cell count in the hematopoietic stem cell and immune cell populations before and after cryopreservation.

The total number of nucleated cells transplanted strongly correlates with clinical outcomes. On average, a typical viable CB unit has a volume of $120 \mathrm{~mL}$ and contains $0.8-3 \times 10^{9}$ TNCs. After processing, a loss of $10-20 \%$ of initially harvested blood was indicated. Generally, the minimum requirement for transplantation is $2.5 \times 10^{7} \mathrm{TNCs}$ per $\mathrm{kg}$ of recipient body weight $[16,17]$. The success of transplantation depends completely on the quality of cryopreserved CB units maintained by the cord bank [18]. To improve the quality 
of cryopreservation in $\mathrm{CB}$ storage, requalification testing prior to the release of a unit utilizing a contiguous segment of $C B$ samples is being developed as a method to confirm unit identity and the growth of hematopoietic progenitor cells before transplantation $[11,19,20]$. In cord blood transplantations, the viability of stem cells is associated with the recovery of patients. The $\mathrm{CB}$ processing method is critical for maintaining the most viable stem cells. In this research, the Rubinstein method was used to collect and process plasma-depleted CB for clinical transplantation [15]. It is important to establish how long CB can be maintained viably in cryogenic storage

Correlation between the duration of storage and transplant outcomes has not been reported. CB units that have been stored for over 10 years have not been used successfully in transplants. There is no consensus regarding the shelf life of $C B$ units, even when stored under suitable conditions in liquid nitrogen. Previously, it was reported that $\mathrm{CB}$ units could be stored for at least 23.5 years with minimal HSC loss [13,21,22]. Herein, we demonstrated the highly efficient recovery of viable cells, TNCs, and CD34+ cells from stored CB. Usually, the hematopoietic potential of CB is estimated by the number of cells expressing the $\mathrm{CD} 34$ antigen with high functionality. The use of cryopreserved $\mathrm{CB}$ in recent times has expanded its range of applications in transplantation and regenerative medicine. Monocytes isolated from cryopreserved CB could be potentially transplanted for treating inherited demyelinating conditions of the central nervous system [23]. Additionally, dendritic cells derived from cryopreserved $\mathrm{CB}$ monocytes were observed to exhibit antitumor potential [24]. Induced pluripotent stem cells were generated from HSCs isolated from 21to 23.5-year-old cryopreserved CB samples that showed optimal storage recovery of HSCs for future clinical utility [22,25]. In addition, the utility of non-manipulated cryopreserved $\mathrm{CB}$ in the treatment of type 1 diabetes and acquired neurological injuries has been assessed in clinical studies $[26,27]$.

Several clinical applications have been determined for over 500 cryopreserved CB units released from private $\mathrm{CB}$ banks. In Korea, there are 17 public and private cord blood banks storing more than 500,000 CB units currently. MEDIPOST Co., Ltd. private cord blood bank, the first private bank in Korea, was established in 2000, and 254,505 units were cryopreserved until December 2020. Until now, 557 CB units were used for either autologous or allogeneic transplants (Table 4). The longest storage period of a CB unit used for transplantation was 17 years. A CB unit stored from 2003 was used for allogenic transplantation in 2020 for a patient with acute myeloid leukemia (Tables 3 and 4). In this study, we analyzed $128 \mathrm{CB}$ units among 557 units that were used for transplantation and have been cryopreserved for $>10$ years. Our study demonstrated that the 557 transplanted $\mathrm{CB}$ units had a higher viability rate and a consistently higher recovery rate of TNCs and CD34+ cells. A large percentage of cryopreserved CB units have been used in clinical applications, such as for the treatment of brain injury, developmental disorders, HSC transplant indication, acquired hearing loss, and autoimmune disorders. Several studies have been conducted to improve outcomes following CB transplantation with minimal manipulations [28]. Our study provided data and compared the cell populations in CB units that had been cryopreserved for 20 years with those in fresh $C B$ units. The findings of this study support the use of $\mathrm{CB}$ units that have undergone long-term cryopreservation and should reassure clinicians regarding the potential of $\mathrm{CB}$ transplantation in other clinical applications besides HSC transplantation.

This study has several limitations. First, clinical results about transplanted CB units were unavailable. Restricted clinical outcomes-including graft-versus-host disease, transplantation-related mortality, relapse, and survival—could not be included in the long-term cryopreservation correlations. In addition, we excluded CB units used in double transplantation to minimize confounding the results. Finally, only CB units with a TNC of $8.0 \times 10^{8}$ cells/unit and over that had been cryopreserved since 2011 were used. Therefore, we did not include the data of cryopreserved CB from 2012 to 2019. CB units with TNCs of under $8.0 \times 10^{8}$ cells/unit were not allowed to cryopreserve. 
Table 4. The number of CB units according to the transplantation and storage year.

\begin{tabular}{|c|c|c|c|c|c|c|c|c|c|c|c|c|c|c|c|c|c|c|c|c|c|}
\hline \multirow{2}{*}{$\begin{array}{l}\text { Storage } \\
\text { Year }\end{array}$} & \multicolumn{21}{|c|}{ Cord Blood Transplantation Year } \\
\hline & 2001 & 2002 & 2003 & 2004 & 2005 & 2006 & 2007 & 2008 & 2009 & 2010 & 2011 & 2012 & 2013 & 2014 & 2015 & 2016 & 2017 & 2018 & 2019 & 2020 & Total \\
\hline 2000 & 3 & 2 & 4 & 5 & 4 & 1 & 3 & & & 1 & & & & & 1 & & & & & & 24 \\
\hline 2001 & 10 & 8 & 18 & 14 & 15 & 22 & 7 & 11 & 3 & 5 & 3 & 6 & 2 & 1 & & & & & & & 125 \\
\hline 2002 & & 1 & 3 & 3 & 5 & 2 & 2 & & 2 & 4 & 4 & 1 & & & & & & & & & 27 \\
\hline 2003 & & & 3 & 22 & 16 & 23 & 10 & 11 & 7 & 7 & 12 & 3 & & 2 & 1 & & 1 & & & 1 & 119 \\
\hline 2004 & & & & 8 & 18 & 32 & 13 & 7 & 9 & 11 & 2 & 2 & 2 & 3 & 1 & & & & & & 108 \\
\hline 2005 & & & & & 1 & 14 & 15 & 7 & 3 & 8 & 1 & 1 & 1 & & & & & & & & 51 \\
\hline 2006 & & & & & & 3 & 7 & 1 & 3 & 2 & 1 & 2 & 2 & 1 & & 1 & & & & & 23 \\
\hline 2007 & & & & & & & 3 & 3 & 7 & 7 & 4 & 2 & 2 & & 1 & & & & & & 29 \\
\hline 2008 & & & & & & & & & & 3 & 2 & & & & 1 & & & & 1 & & 7 \\
\hline 2009 & & & & & & & & & & & 1 & 3 & & 1 & & & & 1 & & & 6 \\
\hline 2010 & & & & & & & & & & & 1 & & 3 & 3 & 2 & 1 & & & & & 10 \\
\hline 2011 & & & & & & & & & & & 2 & 2 & 1 & 1 & 2 & 1 & & 1 & & & 10 \\
\hline 2012 & & & & & & & & & & & & & 2 & & & 1 & & 1 & & & 4 \\
\hline 2013 & & & & & & & & & & & & & & 1 & 1 & 2 & & & & & 4 \\
\hline 2014 & & & & & & & & & & & & & & & 4 & 1 & & & & & 5 \\
\hline 2015 & & & & & & & & & & & & & & & & 1 & 1 & & & & 2 \\
\hline 2016 & & & & & & & & & & & & & & & & 3 & & & & & 3 \\
\hline Total & 13 & 11 & 28 & 52 & 59 & 97 & 60 & 40 & 34 & 48 & 33 & 22 & 15 & 13 & 14 & 11 & 2 & 3 & 1 & 1 & 557 \\
\hline
\end{tabular}

The clinical outcomes of transplantation are influenced by the number of TNCs and CD34+ cells, and by HLA (human leukocyte antigen) matching [29-31]. However, the reduced $\mathrm{CB}$ volume post-processing has not been observed to affect transplantation outcomes [32,33]. Cryopreservation for future use and establishment of insurance reimbursement have met the increasing demand for precision health care. The safety and success of $\mathrm{CB}$ transplantation relies on the integrity of cryopreservation conditions. Loss of integrity during long-term storage can lead to failures in CB maintenance and errors in the quality assessment of stored CB units $[12,18,20]$. The stability of long-term cryopreserved CB has to be based on the satisfactory recovery of TNCs and viable CD34+ cells after long-term storage. In order to evaluate the cryopreservation and storage over time on the stability and quality of CB units, the viability of TNC and CD34+ cells of each segment from cryopreserved $\mathrm{CB}$ units were analyzed annually in this study. With high CD34+ cells' viability and a consistently high recovery rate of TNCs, the storage process in a bank is stabilized, reliably controlling the quality of thawed cells. We also confirmed the functional viability and potency of MNCs and CD34+ cells with an evaluation by CFU-GM assay. In this study, we demonstrated that the duration of cryopreservation did not significantly affect the recovery of viability, TNCs, and CD34+ cells, which is vital for successful transplantation. In clinical practice, the use of $\mathrm{CB}$ units stored for more than 10 years is avoided in general cases and transplantations [34,35]. The findings of this study are critical in this context, as they provide evidence that the long-term cryopreservation of $\mathrm{CB}$ is not detrimental to the outcomes of recovery of viable cells and TNCs.

The limitation of HSC transplantation is the reduced viability and poor cell quality after thawing of specimens with a long cryopreservation period. However, our study demonstrated that the quality of cryopreserved CB units did not correlate with the cryopreservation period. Although the cryopreservation and thawing processes may damage cord blood cells, the cell loss is less likely to affect the viability and recovery of CD34+ cells and TNCs. Furthermore, long-term cryopreservation did not affect the immune cell population, which could be utilized in future clinical applications. These results support the use of $\mathrm{CB}$ units that have undergone long-term cryopreservation and provide assuring evidence in favor of the clinical applicability of cryopreserved CB. 
Supplementary Materials: The following are available online at https:/ / www.mdpi.com/2077-038 3/10/2/293/s1. Figure S1: White blood cell populations in total and mononuclear cells isolated from cryopreserved and fresh CB.

Author Contributions: Conceptualization, W.O. and S.U.; data curation, G.-H.K., J.K., and S.H.K.; formal analysis, G.-H.K., J.K., and S.U.; investigation, G.-H.K. and S.H.K.; methodology, G.-H.K., J.K., S.H.K., H.J.K., and S.U.; project administration, H.K.H., H.J.J., S.J.C., W.O., and S.U.; resources, S.H.K., H.J.K., H.K.H., S.J.C., and W.O.; supervision, H.K.H., H.J.J., S.J.C., and W.O.; visualization, G.-H.K. and J.K.; writing-original draft, W.O. and S.U.; writing-review and editing, H.J.J., W.O., and S.U. All authors have read and agreed to the published version of the manuscript.

Funding: This research received no external funding.

Institutional Review Board Statement: The study was conducted in accordance with the Declaration of Helsinki, and the protocol was approved by the Korean Public Institutional Review Board (P01202002-31-001).

Informed Consent Statement: Informed consent was obtained from all subjects involved in the study.

Data Availability Statement: The data presented in this study are available on request from the corresponding author.

Conflicts of Interest: The authors declare no conflict of interest.

\section{References}

1. Park, B.; Yoo, K.H.; Kim, C. Hematopoietic stem cell expansion and generation: The ways to make a breakthrough. Blood Res. 2015, 50, 194-203. [CrossRef] [PubMed]

2. Alkindi, S.; Dennison, D. Umbilical Cord Blood Banking and Transplantation: A short review. Sultan Qaboos Univ. Med. J. 2011, 11, 455-461. [PubMed]

3. Sanz, J.; Veys, P.; Rocha, V. Umbilical Cord Blood Transplantation in Children and Adults. In The EBMT Handbook: Hematopoietic Stem Cell Transplantation and Cellular Therapies; Carreras, E., Dufour, C., Mohty, M., Kroger, N., Eds.; Springer Nature: Cham, Switzerland, 2019; pp. 473-478. [CrossRef]

4. Mayani, H.; Wagner, J.E.; Broxmeyer, H.E. Cord blood research, banking, and transplantation: Achievements, challenges, and perspectives. Bone Marrow Transpl. 2020, 55, 48-61. [CrossRef] [PubMed]

5. Rosenau, E.H.; Sugrue, M.W.; Haller, M.; Fisk, D.; Kelly, S.S.; Chang, M.; Hou, W.; Eldjerou, L.; Slayton, W.; Cogle, C.R.; et al. Characteristics of thawed autologous umbilical cord blood. Transfusion 2012, 52, 2234-2242. [CrossRef]

6. Arutyunyan, I.; Fatkhudinov, T.; Sukhikh, G. Umbilical cord tissue cryopreservation: A short review. Stem Cell Res. Ther. 2018, 9, 236. [CrossRef]

7. Jiang, X.S.; Chai, C.; Zhang, Y.; Zhuo, R.X.; Mao, H.Q.; Leong, K.W. Surface-immobilization of adhesion peptides on substrate for ex vivo expansion of cryopreserved umbilical cord blood CD34+ cells. Biomaterials 2006, 27, 2723-2732. [CrossRef]

8. Waller-Wise, R. Umbilical cord blood: Information for childbirth educators. J. Perinat. Educ. 2011, 20, 54-60. [CrossRef]

9. Moise, K.J., Jr. Umbilical cord stem cells. Obstet. Gynecol. 2005, 106, 1393-1407. [CrossRef]

10. Wall, D.A. Issues in the quality of umbilical cord blood stem cells for transplantation: Challenges in cord blood banking quality management. Transfusion 2005, 45, 826-828. [CrossRef]

11. Querol, S.; Gomez, S.G.; Pagliuca, A.; Torrabadella, M.; Madrigal, J.A. Quality rather than quantity: The cord blood bank dilemma. Bone Marrow Transpl. 2010, 45, 970-978. [CrossRef]

12. Yang, H.; Loutfy, M.R.; Mayerhofer, S.; Shuen, P. Factors affecting banking quality of umbilical cord blood for transplantation. Transfusion 2011, 51, 284-292. [CrossRef] [PubMed]

13. Broxmeyer, H.E.; Srour, E.F.; Hangoc, G.; Cooper, S.; Anderson, S.A.; Bodine, D.M. High-efficiency recovery of functional hematopoietic progenitor and stem cells from human cord blood cryopreserved for 15 years. Proc. Natl. Acad. Sci. USA 2003, 100, 645-650. [CrossRef] [PubMed]

14. Jin, H.J.; Lee, H.J.; Heo, J.; Lim, J.; Kim, M.; Kim, M.K.; Nam, H.Y.; Hong, G.H.; Cho, Y.S.; Choi, S.J.; et al. Senescence-Associated MCP-1 Secretion Is Dependent on a Decline in BMI1 in Human Mesenchymal Stromal Cells. Antioxid. Redox Signal. 2016, 24 471-485. [CrossRef] [PubMed]

15. Rubinstein, P.; Dobrila, L.; Rosenfield, R.E.; Adamson, J.W.; Migliaccio, G.; Migliaccio, A.R.; Taylor, P.E.; Stevens, C.E. Processing and cryopreservation of placental/umbilical cord blood for unrelated bone marrow reconstitution. Proc. Natl. Acad. Sci. USA 1995, 92, 10119-10122. [CrossRef]

16. Butler, M.G.; Menitove, J.E. Umbilical cord blood banking: An update. J. Assist. Reprod. Genet. 2011, 28, 669-676. [CrossRef]

17. Cohen, Y.C.; Scaradavou, A.; Stevens, C.E.; Rubinstein, P.; Gluckman, E.; Rocha, V.; Horowitz, M.M.; Eapen, M.; Nagler, A.; Shpall, E.J.; et al. Factors affecting mortality following myeloablative cord blood transplantation in adults: A pooled analysis of three international registries. Bone Marrow Transpl. 2011, 46, 70-76. [CrossRef] 
18. Allan, D.; Petraszko, T.; Elmoazzen, H.; Smith, S. A review of factors influencing the banking of collected umbilical cord blood units. Stem Cells Int. 2013, 2013, 463031. [CrossRef]

19. Goodwin, H.S.; Grunzinger, L.M.; Regan, D.M.; McCormick, K.A.; Johnson, C.E.; Oliver, D.A.; Mueckl, K.A.; Alonso, J.M., 3rd; Wall, D.A. Long term cryostorage of UC blood units: Ability of the integral segment to confirm both identity and hematopoietic potential. Cytotherapy 2003, 5, 80-86. [CrossRef]

20. Thyagarajan, B.; Berger, M.; Sumstad, D.; McKenna, D.H., Jr. Loss of integrity of umbilical cord blood unit freezing bags: Description and consequences. Transfusion 2008, 48, 1138-1142. [CrossRef]

21. Broxmeyer, H.E.; Cooper, S. High-efficiency recovery of immature haematopoietic progenitor cells with extensive proliferative capacity from human cord blood cryopreserved for 10 years. Clin. Exp. Immunol. 1997, 107, 45-53.

22. Broxmeyer, H.E.; Lee, M.R.; Hangoc, G.; Cooper, S.; Prasain, N.; Kim, Y.J.; Mallett, C.; Ye, Z.; Witting, S.; Cornetta, K.; et al. Hematopoietic stem/progenitor cells, generation of induced pluripotent stem cells, and isolation of endothelial progenitors from 21- to 23.5-year cryopreserved cord blood. Blood 2011, 117, 4773-4777. [CrossRef]

23. Saha, A.; Buntz, S.; Scotland, P.; Xu, L.; Noeldner, P.; Patel, S.; Wollish, A.; Gunaratne, A.; Gentry, T.; Troy, J.; et al. A cord blood monocyte-derived cell therapy product accelerates brain remyelination. JCI Insight 2016, 1, e86667. [CrossRef] [PubMed]

24. Than, U.T.T.; Le, H.T.; Hoang, D.H.; Nguyen, X.H.; Pham, C.T.; Bui, K.T.V.; Bui, H.T.H.; Nguyen, P.V.; Nguyen, T.D.; Do, T.T.H.; et al. Induction of Antitumor Immunity by Exosomes Isolated from Cryopreserved Cord Blood Monocyte-Derived Dendritic Cells. Int. J. Mol. Sci. 2020, 21, 1834. [CrossRef] [PubMed]

25. Roh, E.Y.; Oh, S.; Yoon, J.H.; Kim, B.J.; Song, E.Y.; Shin, S. Umbilical Cord Blood Units Cryopreserved in the Public Cord Blood Bank: A Breakthrough in iPSC Haplobanking? Cell Transpl. 2020, 29, 963689720926151. [CrossRef] [PubMed]

26. Haller, M.J.; Wasserfall, C.H.; Hulme, M.A.; Cintron, M.; Brusko, T.M.; McGrail, K.M.; Sumrall, T.M.; Wingard, J.R.; Theriaque, D.W.; Shuster, J.J.; et al. Autologous umbilical cord blood transfusion in young children with type 1 diabetes fails to preserve C-peptide. Diabetes Care 2011, 34, 2567-2569. [CrossRef] [PubMed]

27. Haller, M.J.; Wasserfall, C.H.; Hulme, M.A.; Cintron, M.; Brusko, T.M.; McGrail, K.M.; Wingard, J.R.; Theriaque, D.W.; Shuster, J.J.; Ferguson, R.J.; et al. Autologous umbilical cord blood infusion followed by oral docosahexaenoic acid and vitamin D supplementation for C-peptide preservation in children with Type 1 diabetes. Biol. Blood Marrow Transpl. 2013, 19, 1126-1129. [CrossRef] [PubMed]

28. Brown, K.S.; Rao, M.S.; Brown, H.L. The Future State of Newborn Stem Cell Banking. J. Clin. Med. 2019, 8, 117. [CrossRef]

29. Migliaccio, A.R.; Adamson, J.W.; Stevens, C.E.; Dobrila, N.L.; Carrier, C.M.; Rubinstein, P. Cell dose and speed of engraftment in placental/umbilical cord blood transplantation: Graft progenitor cell content is a better predictor than nucleated cell quantity. Blood 2000, 96, 2717-2722. [CrossRef]

30. Purtill, D.; Smith, K.; Devlin, S.; Meagher, R.; Tonon, J.; Lubin, M.; Ponce, D.M.; Giralt, S.; Kernan, N.A.; Scaradavou, A.; et al. Dominant unit CD34+ cell dose predicts engraftment after double-unit cord blood transplantation and is influenced by bank practice. Blood 2014, 124, 2905-2912. [CrossRef]

31. Barker, J.N.; Scaradavou, A.; Stevens, C.E. Combined effect of total nucleated cell dose and HLA match on transplantation outcome in 1061 cord blood recipients with hematologic malignancies. Blood 2010, 115, 1843-1849. [CrossRef]

32. Nikiforow, S.; Li, S.; Snow, K.; Liney, D.; Kao, G.S.; Haspel, R.; Shpall, E.J.; Glotzbecker, B.; Sica, R.A.; Armand, P.; et al. Lack of impact of umbilical cord blood unit processing techniques on clinical outcomes in adult double cord blood transplant recipients. Cytotherapy 2017, 19, 272-284. [CrossRef] [PubMed]

33. Ballen, K.K.; Logan, B.R.; Laughlin, M.J.; He, W.; Ambruso, D.R.; Armitage, S.E.; Beddard, R.L.; Bhatla, D.; Hwang, W.Y.; Kiss, J.E.; et al. Effect of cord blood processing on transplantation outcomes after single myeloablative umbilical cord blood transplantation. Biol. Blood Marrow Transpl. 2015, 21, 688-695. [CrossRef] [PubMed]

34. Mitchell, R.; Wagner, J.E.; Brunstein, C.G.; Cao, Q.; McKenna, D.H.; Lund, T.C.; Verneris, M.R. Impact of long-term cryopreservation on single umbilical cord blood transplantation outcomes. Biol. Blood Marrow Transpl. 2015, 21, 50-54. [CrossRef] [PubMed]

35. Wall, D.A. Regulatory issues in cord blood banking and transplantation. Best Pract. Res. Clin. Haematol. 2010, $23,171-177$. [CrossRef] 